\title{
Molecular pathology of vertebral deformities in hyperthermic Atlantic salmon (Salmo salar)
}

Elisabeth Ytteborg ${ }^{1,2}$, Grete Baeverfjord ${ }^{1}$, Jacob Torgersen ${ }^{1}$, Kirsti Hjelde ${ }^{1}$, Harald Takle ${ }^{1,3^{*}}$

\begin{abstract}
Background: Hyperthermia has been shown in a number of organisms to induce developmental defects as a result of changes in cell proliferation, differentiation and gene expression. In spite of this, salmon aquaculture commonly uses high water temperature to speed up developmental rate in intensive production systems, resulting in an increased frequency of skeletal deformities. In order to study the molecular pathology of vertebral deformities, Atlantic salmon was subjected to hyperthermic conditions from fertilization until after the juvenile stage.

Results: Fish exposed to the high temperature regime showed a markedly higher growth rate and a significant higher percentage of deformities in the spinal column than fish reared at low temperatures. By analyzing phenotypically normal spinal columns from the two temperature regimes, we found that the increased risk of developing vertebral deformities was linked to an altered gene transcription. In particular, down-regulation of extracellular matrix (ECM) genes such as col1a1, osteocalcin, osteonectin and decorin, indicated that maturation and mineralization of osteoblasts were restrained. Moreover, histological staining and in situ hybridization visualized areas with distorted chondrocytes and an increased population of hypertrophic cells. These findings were further confirmed by an up-regulation of mef2c and col10a, genes involved in chondrocyte hypertrophy.
\end{abstract}

Conclusion: The presented data strongly indicates that temperature induced fast growth is severely affecting gene transcription in osteoblasts and chondrocytes; hence change in the vertebral tissue structure and composition. A disrupted bone and cartilage production was detected, which most likely is involved in the higher rate of deformities developed in the high intensive group. Our results are of basic interest for bone metabolism and contribute to the understanding of the mechanisms involved in development of temperature induced vertebral pathology. The findings may further conduce to future molecular tools for assessing fish welfare in practical farming.

\section{Background}

Industrial fish farming makes use of intensive production regimes in an effort to decrease production time and costs. Elevated water temperatures are commonly applied, often without explicit control of factors like nutrition, water quality, densities and vaccination. The intensive rearing systems are unfortunately correlated with deformities affecting both skeletal and soft tissues $[1,2]$. In teleosts, hyperthermia can induce vertebral deformities both during the embryonic development and after the vertebral column has been established [3-5]

\footnotetext{
* Correspondence: harald.takle@nofima.no

${ }^{1}$ Nofima Marin, Norwegian Institute of Food, Fisheries and Aquaculture Research, P.O. Box 5010, NO-1432 Ås, Norway
}

The teleost vertebral body is built using a minimal bone mass to reduce negative buoyancy [6]. In salmon, the vertebral body comprises four mineralized or ossified layers. Formation of the different layers involves the balanced and highly regulated formation of bone and cartilaginous structures through patterns of mineralization and matrix deposition [7]. The specialized architecture makes it vulnerable to alterations in its tissue composition. Intramembranous ossification occurs by coordinated processes of production, maturation and mineralization of osteoid matrix [8]. Initially osteoblasts produce a thickening osteoid seam by collagen deposition without mineralization. This is followed by an increase in the mineralization rate and the final stage where collagen synthesis decreases and mineralization
C Biomed Central 
continues until the osteoid seam is fully mineralized. As part of the process, mineralization time lag appears to be required for allowing modifications of the osteoid so that it is able to support mineralization [9]. Indeed, fast growing Atlantic salmon has been shown to exhibit low vertebral mineral content and mechanical strength, together with an increased risk of developing vertebral deformities $[10,11]$.

Skeletal growth depends upon the dynamic equilibrium between cartilage production and bone apposition rate [12]. Ontogeny and growth of the vertebral column is under control of regulatory mechanisms involving transcription factors, signaling molecules and extracellular matrix proteins. The pathways of chondrocyte and osteoblast differentiation are interconnected during vertebral formation and must be coordinated. In particular, regulatory proteins, like the transcription factors Sox9, Runx2, Osterix, Twist and Mef2c have distinct functions both in the establishment of the vertebral bodies and later in the differentiation and maturation of specific skeletal cell types (review [13]). Similarly, signaling molecules like bone morphogenetic proteins (Bmp2 and Bmp4), and hedgehog proteins (Ihh and Shh) plays different roles both during cell differentiation and skeletal tissue ontogeny [14-16]. Osteoblasts and chondrocytes secrete the collagen fibers and ground substances of bone and cartilage. These cells are also responsible for the mineralization of the matrix through secretion of specialized molecules, such as Alkaline phosphatase (ALP), Osteocalcin and Osteonectin that binds inorganic minerals $[17,18]$. A widely accepted view is that the spatial restriction of ECM mineralization to bone is explained by osteoblast-specific gene products that initiate the formation of hydroxyapatite crystals $\left(\mathrm{Ca}_{10}\left[\mathrm{PO}_{4}\right]^{6}\right.$ $[\mathrm{OH}]^{2}$ ) [19]. The requirement for specifically expressed genes in osteoblasts (e.g. col1, osteocalcin and osteonectin) and chondrocytes (e.g. col2 and col10) to initiate the formation of matrix or control the growth of hydroxyapatite crystals is supported by numerous studies $[18,20,21]$. Furthermore, Matrix metalloproteinases (MMPs) and Tartrate-resistant acid phosphatase (TRAP) are involved in degradation of ECM and in the bone remodeling process performed by the osteoclasts [22].

In this work, 20 skeletal genes were used to study the effect of long term hyperthermic exposure on vertebral development and growth in Atlantic salmon. Fish exposed to high temperature (high intensive regime) had a significant higher incidence of deformities than fish from the same origin reared under a conservative temperature regime (low intensive regime). The study was aimed at exposing differences in risk level between the groups, rather than elaborating the pathologies of deformed vertebrae, hence, the study concentrated on phenotypically normal fish from both temperatures.
Significant changes in gene transcription were found between phenotypically normal vertebrae of both groups, including down-regulation of genes encoding proteins important for mineralization. Further, in situ hybridization $(I S H)$ and histological staining revealed phenotypical and functional changes in the arch centra. Our results are of basic interest for understanding bone metabolism and deformities, as well as a tool for assessing fish welfare in practical farming.

\section{Results}

In the present study we analyzed and compared Atlantic salmon vertebrae from high and low temperature intensity regimes. Rate of development and growth was influenced by temperature regime as observed through SGR and time of sampling. The development from fertilization to first feeding lasted 5 months in the low intensive regime at $6^{\circ} \mathrm{C}$, compared to 3 months in the high intensive regime at $10^{\circ} \mathrm{C}$. Juveniles of the high intensive group also grew more rapidly after start-feeding than the low intensive group, where the former reached $2 \mathrm{~g}$ in 6 weeks after first feeding, $15 \mathrm{~g}$ in 3 months and $60 \mathrm{~g}$ in 7 months after first feeding, at a rearing temperature of $16^{\circ} \mathrm{C}$. In comparison, the low intensive group at rearing temperature of $10^{\circ} \mathrm{C}$ reached similar sizes in 11 weeks, 5 months and 10 months, respectively. Accordingly, after start-feeding fish from the high intensive temperature regime displayed a higher SGR than the low temperature fish, 2.82 and 1.96 respectively.

\section{Radiography, morphology and mineral analyses}

On radiography analysis, the incidence of fish with skeletal abnormalities at $2 \mathrm{~g}$ size was $4.0 \pm 2.8 \%$ and $10.0 \pm$ $1.7 \%$ in the low and high intensive groups, respectively (n.s.; not significant). At $15 \mathrm{~g}$ size, the difference was more pronounced, $3.4 \pm 2.0 \%$ and $17.9 \pm 1.3 \%$ (p < $0.001)$. At the final sampling at $60 \mathrm{~g}$ size, $8 \pm 1.4 \%$ of the fish in the low intensive group displayed some degree of skeletal pathology compared to $28.1 \pm 2.3 \%$ in the high intensive group $(\mathrm{p}<0.0001)$, results are shown in figure 1.

Morphometric analyses of vertebral shape demonstrated that fish classified as having a normal phenotype in both groups had more or less regularly shaped vertebrae, but that there was a difference in length-height proportion of vertebrae between fish from the two temperature regimes. Measurements on X-ray images showed that vertebral bodies from the high intensive groups were significantly shorter in craniocaudal direction compared to those from the low intensive groups. The ratios for the high and low intensive group were at $2 \mathrm{~g} 0.68 \pm 0.02$ and $0.76 \pm 0.02$, at $15 \mathrm{~g} 0.78 \pm 0.03$ and $0.89 \pm 0.06$ and at $60 \mathrm{~g} 0.86 \pm 0.01$ and $0.94 \pm 0.01$, respectively $(\mathrm{p}<0.001)$. Examples of vertebral columns 


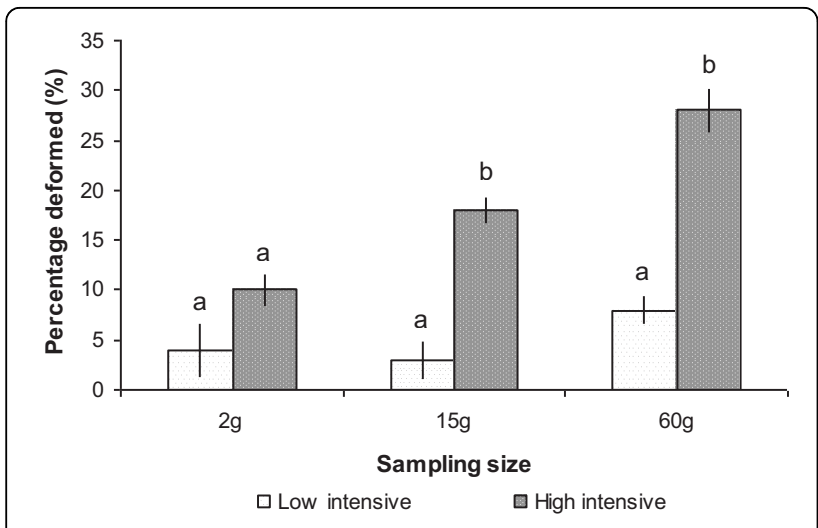

Figure 1 Frequency (\%) of deformities in the vertebral column based on radiographic examination of Atlantic salmon sampled from the low temperature intensive group (white bars) and the high temperature intensive group (black bars) from fertilization until $60 \mathrm{~g}$. Each bar represents the total number of deformities, scored as present or absent. Data are given in percentage \pm st.dev, different letters indicate significant differences $(P \leq 0.01)$ within the same size group, $n=4$ tanks per treatment.

with normal phenotype from the high and low intensive group at $15 \mathrm{~g}$ are shown in figure 2 .

Due to the built-in image contrast enhancement procedures of the semi-digital X-ray system, evaluation of skeletal mineralization as judged by radio density in images was impaired. Nevertheless, a lower contrast in skeletal structures was observed in the high intensity fish, in particular at the $15 \mathrm{~g}$ sampling, indicative of a lower mineralization rate at this stage.
Whole body mineral content at the end of the experiment (60 g size) showed low values for $\mathrm{Ca}, \mathrm{P}$ and $\mathrm{Zn}$ content for both temperature regimes (Table 1), with no significant differences between treatments. There was a small, but significant lower level of whole body Fe and $\mathrm{Na}$ in the high intensive group. All Fe and $\mathrm{Na}$ values were lower than reference values [23], but in correspondence with $\mathrm{Ca}, \mathrm{P}$ and $\mathrm{Zn}$ values, they were within a range which is commonly seen in commercially reared salmon.

\section{Quantitative vertebral mRNA expression}

The skeletal genes were divided into three groups according to function; ECM constituents, transcription factors, and signaling molecules (Figure 3A-C).

ECM constituents included genes involved in bone matrix production and mineralization and 7 out of 9 of these genes were found to be down-regulated in high intensive group at 2 and 15 g (Figure 3A). Transcription of colla1, osteocalcin, decorin, osteonectin, $m m p 9$ and $m m p 13$ were reduced in the high intensive group compared to the low intensive group. Col2a 1 transcription was also down-regulated at both developmental stages, however the values were insignificant. Osteocalcin was severely down-regulated in $2 \mathrm{~g}$ high intensive group. Converse transcription profiles could be observed for col10a 1 and alp between $2 \mathrm{~g}$ and $15 \mathrm{~g}$ fish; col10a1 was down-regulated at $2 \mathrm{~g}$ and up-regulated at $15 \mathrm{~g}$ whereas alp was up-regulated at $2 \mathrm{~g}$ and down-regulated at $15 \mathrm{~g}$.
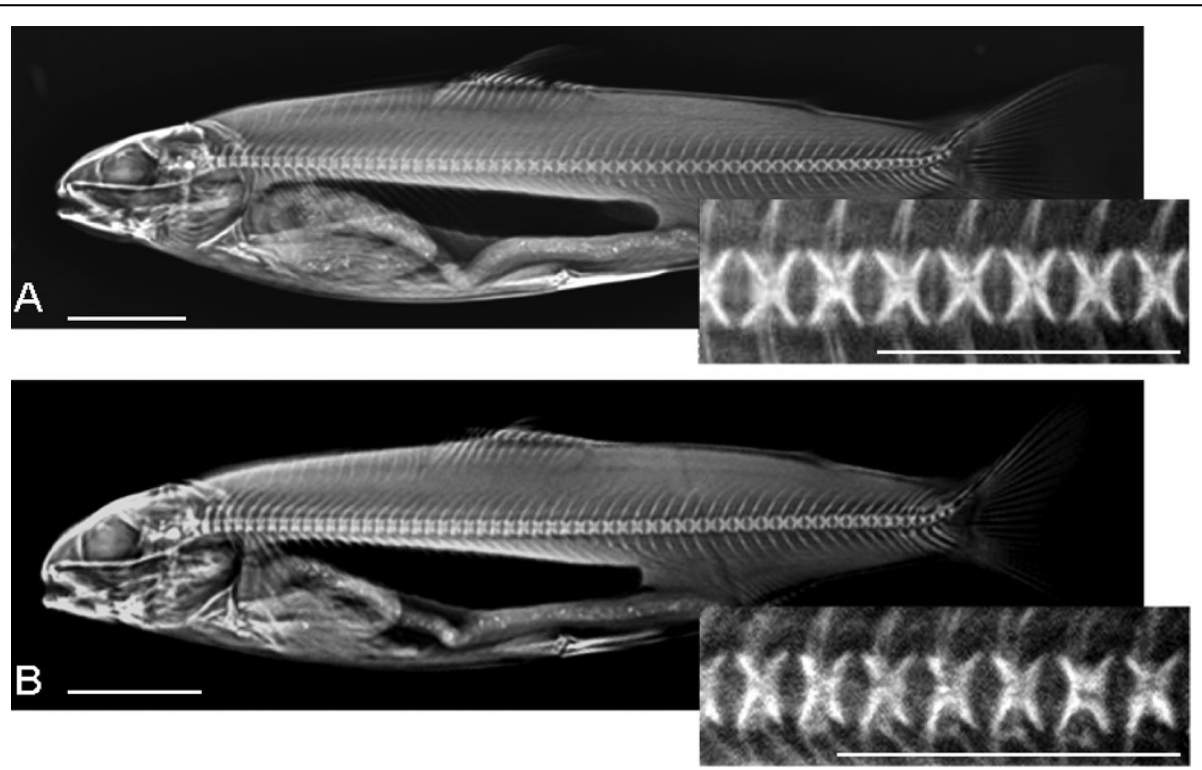

Figure 2 Radiographic images of Atlantic salmon at $15 \mathrm{~g}$ from the low temperature intensive group (A) and the high temperature intensive group (B). Scale bar $=1.5 \mathrm{~cm}$. Enlarged picture (to the right) corresponds to the dissected area from underneath the dorsal fin. Scale bar $=1 \mathrm{~cm}$. 
Table 1 Mineral analysis

\begin{tabular}{lll}
\hline & Low intensive group & High intensive group \\
\hline $\mathrm{P}$ & $3828 \pm 162$ & $3886 \pm 285$ \\
$\mathrm{Ca}$ & $3655 \pm 341$ & $3700 \pm 677$ \\
$\mathrm{Mg}$ & $302.3 \pm 8$ & $299 \pm 7$ \\
$\mathrm{Na}$ & $1303 \pm 70$ & $1084 \pm 87^{*}$ \\
$\mathrm{Fe}$ & $9.7 \pm 1.2$ & $8.1 \pm 0.2^{*}$ \\
$\mathrm{Mn}$ & $0.86 \pm 0.05$ & $0.8 \pm 0.09$ \\
$\mathrm{Zn}$ & $31.8 \pm 2.6$ & $33.5 \pm 1.7$ \\
$\mathrm{Cu}$ & $0.8 \pm 0.12$ & $0.7 \pm 0.09$ \\
\hline
\end{tabular}

Mineral content (ppm) in whole body of Atlantic salmon at $60 \mathrm{~g}$ from low and high intensive temperature group. Total mineral content was measured in whole fish. Levels were low, but within the range of what are common in commercially reared salmon. Significant numbers $(P=0.05)$ indicated by *, $n=40$ (means \pm st.dev).
Temporal changes in transcription factor mRNA expression were found between high and low temperature group, and all genes except sox 9 showed opposite expression at 2 and $15 \mathrm{~g}$ (Figure 3B). In the high intensive group, sox 9 was down-regulated at $2 \mathrm{~g}$ (n.s.) and $15 \mathrm{~g}$, but more pronounced in the latter. Investigation of the two osteoblast markers runx 2 and osterix, revealed opposite mRNA expression levels at 2 and 15 g. Run $x 2$ was upregulated at $2 \mathrm{~g}$ (n.s), but down-regulated at $15 \mathrm{~g}$. On the contrary, osterix was down-regulated (n.s.) at $2 \mathrm{~g}$, but upregulated at $15 \mathrm{~g}$. Mef $2 c$ and twist was also down-regulated at $2 \mathrm{~g}$, while up-regulated at $15 \mathrm{~g}$ (twist n.s.).

Signaling molecules included bmp2, bmp4, shh and $i h h$. Expression analysis of mRNA for signaling mole-
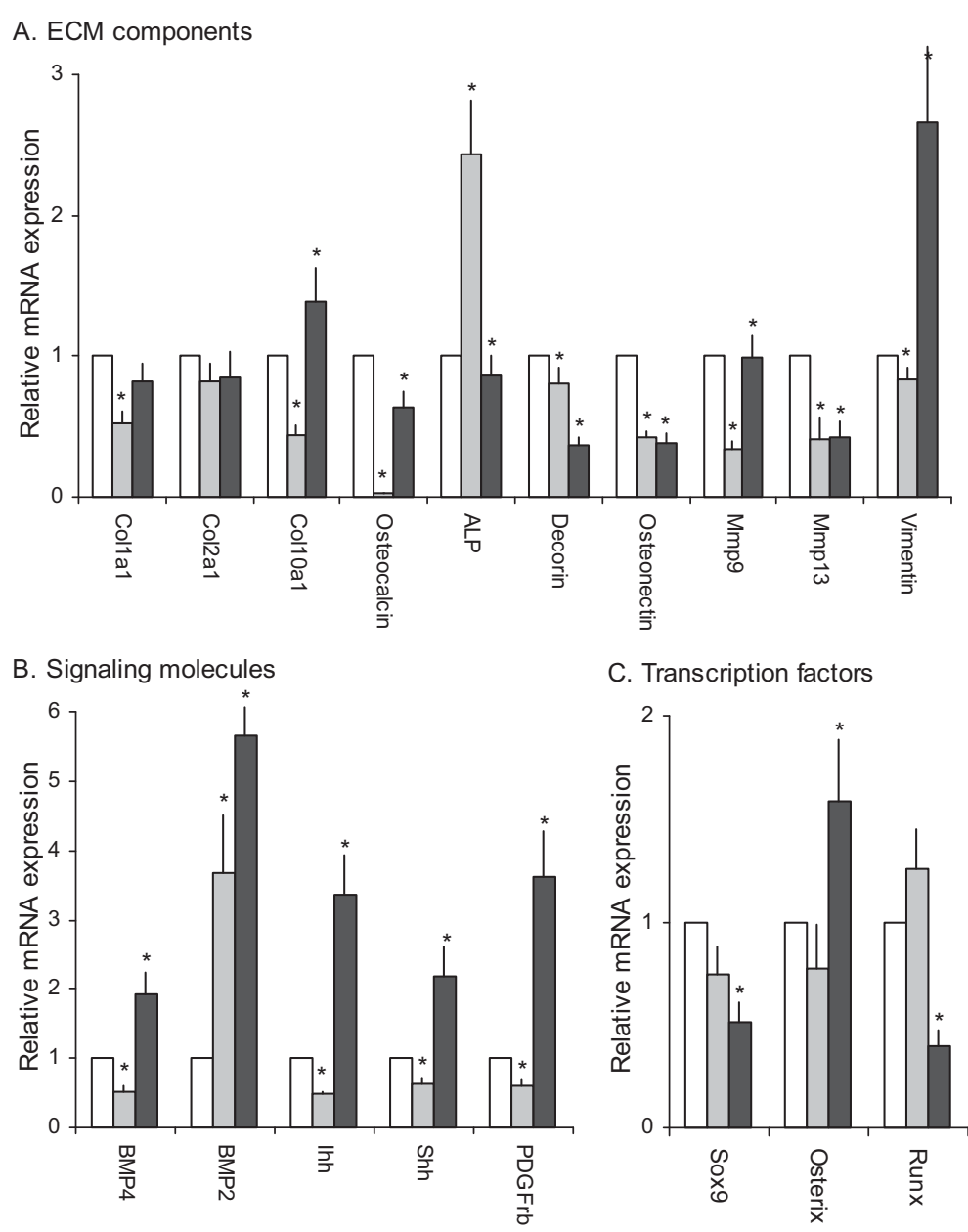

C. Transcription factors

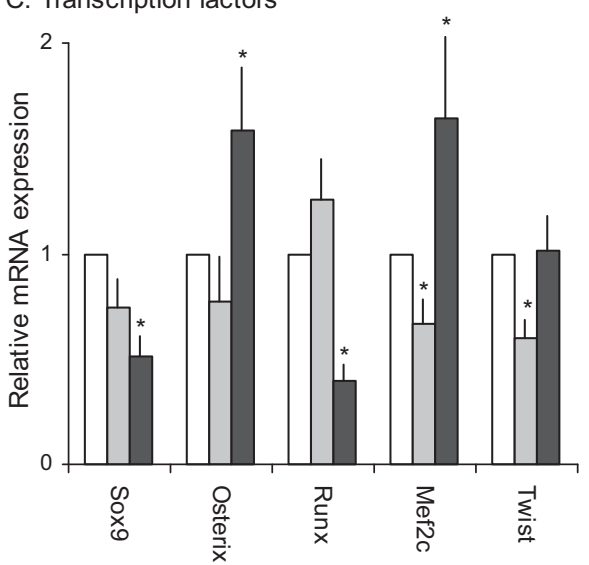

$\square$ Low temperature $\square 2 \mathrm{~g}$ high temperature $\square 15 \mathrm{~g}$ high temperature

Figure 3 Relative gene transcription of A. ECM components, B. Signaling molecules and C. Transcription factors in phenotypical normal spinal columns from $2 \mathrm{~g}$ (grey bars) and $15 \mathrm{~g}$ (black bars) high temperature intensive group compared to the low temperature intensive group (white bars). Data are given as mean values $+S E, n=15$ and significant differences $(P=0.05)$ are indicated by *. Expression ratios are shown in relative mRNA expression along the $y$-axis, genes along the $x$-axis. 
cules showed statistically significant differences in expression levels between the temperature regimes and all transcripts were found more abundant in the $15 \mathrm{~g}$ group when compared to $2 \mathrm{~g}$ vertebrae. $B m p 2$ was the only up-regulated signaling molecule at $2 \mathrm{~g}$, while all signaling genes were up-regulated at $15 \mathrm{~g}$ (Figure $3 \mathrm{C}$ ).

To further examine changes in chondrocyte recruitment and structure between the temperature regimes, we included platelet derived growth factor receptor $b$ (pdgfrb) and vimentin, because of their importance in proliferation and the cytoskeleton, respectively [24,25]. Both transcripts were significantly down-regulated in $2 \mathrm{~g}$, while significantly up-regulated at $15 \mathrm{~g}$ (Figure 3A, B).

In summary, we found that out of the 20 genes we analyzed, 8 were down-regulated in both temperature groups (col1a1, col2a1, osteocalcin, sox9, decorin, osteonectin, mmp9 and mmp13), 9 genes were up-regulated in the $15 \mathrm{~g}$ high intensive group, but down-regulated at 2 g (bmp4, col10a1, osterix, ihh, shh, mef2c, twist, vimentin and pdgfrb). And finally, alp and runx 2 were upregulated at $2 \mathrm{~g}$ but down-regulated at $15 \mathrm{~g}$.

\section{Vertebral tissue morphology and spatial mRNA expression}

In areas where osteoblasts secrete the osteoid matrix, a generally stronger ISH signals was apparent in the low intensive group for all probes. The osteogenic marker gene colla showed distinct staining to osteoblasts at the growth zone of the endbones of the vertebral bodies from fish of both temperature regimes (Figure 4A-C). Moreover, colla signal was identified in the bone lining osteoblast cells situated at the lateral surfaces of the trabeculae and along the rims of the vertebral bodies. Investigation of osteocalcin mRNA revealed an expression pattern similar to colla, with staining of cells in the osteogenous areas and in bone lining osteoblasts and apical surfaces of the trabeculae (Figure 4D-G). Specifically high osteocalcin signal was detected in the proliferative osteoblast growth zones on the endbones of the vertebral bodies. Osteonectin mRNA was detected in the osteogenic growth zone of the endbones and lining the exterior part of the vertebral body (Figure 5A-D). The chondrocytic marker col $2 a$, hybridized heavily to chordoblasts in the notochord (Figure 5E-G), whereas col10a was detected in a continuous layer of cells along the rims of the vertebral body (Figure 5J-L).

Alizarin red $S$ and toluidine blue stained chondrocytes in the arch centra and revealed distinct morphological differences between vertebrae from the two temperature groups. The low intensive group was defined by distinct sub-groups of chondrocytes in the different maturational stages i.e. resting, proliferating and hypertrophic. In contrast, the equivalent chondrocytes were more distorted in the high intensive group (Figure 6A, B). ISH analysis of col2a, col10a and osteonectin enabled classification of the different chondrocytes into distinct sub-populations of maturational development. Col $2 a$ hybridized to resting and pre-hypertrophic chondrocytes in two distinct

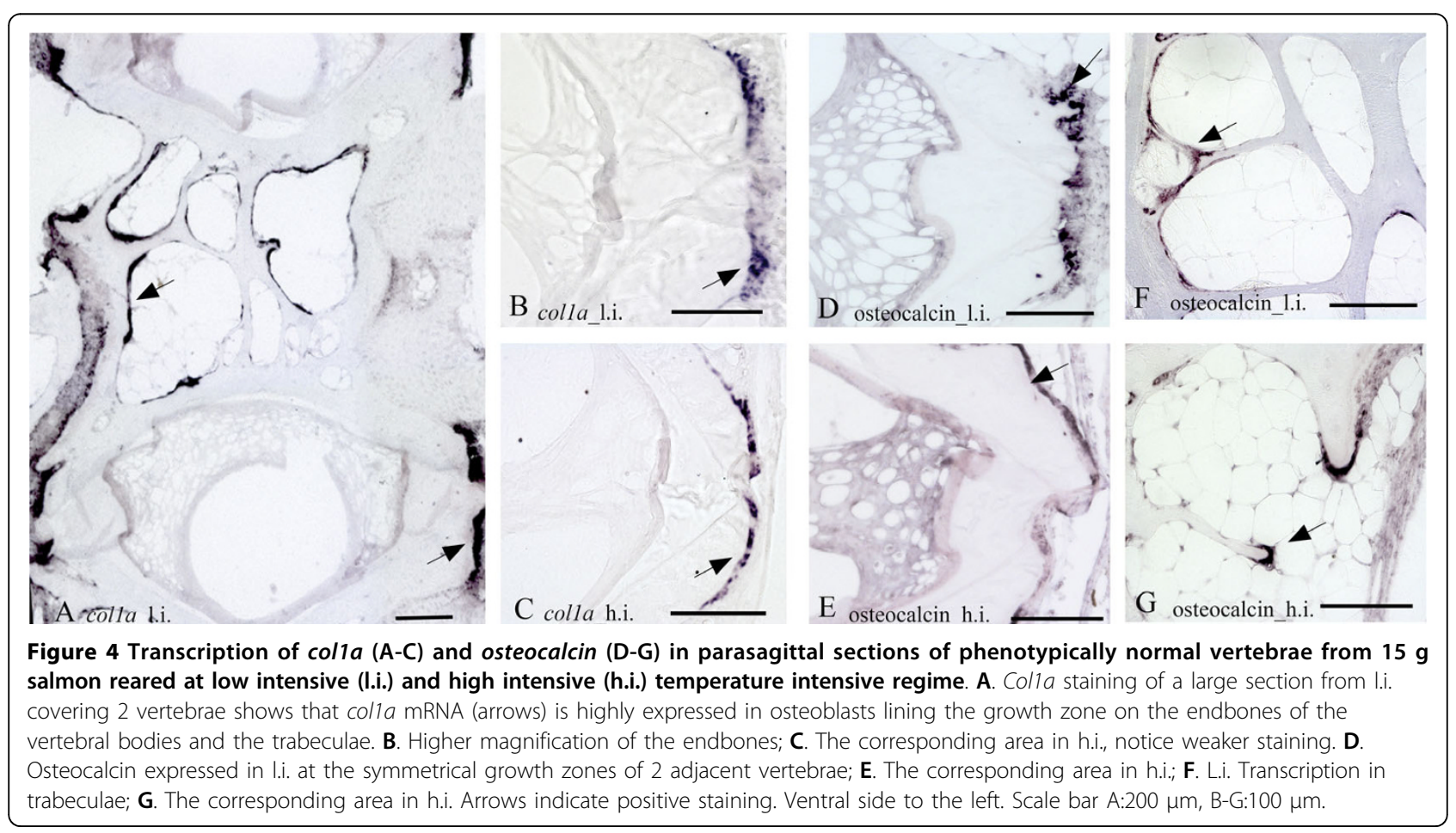



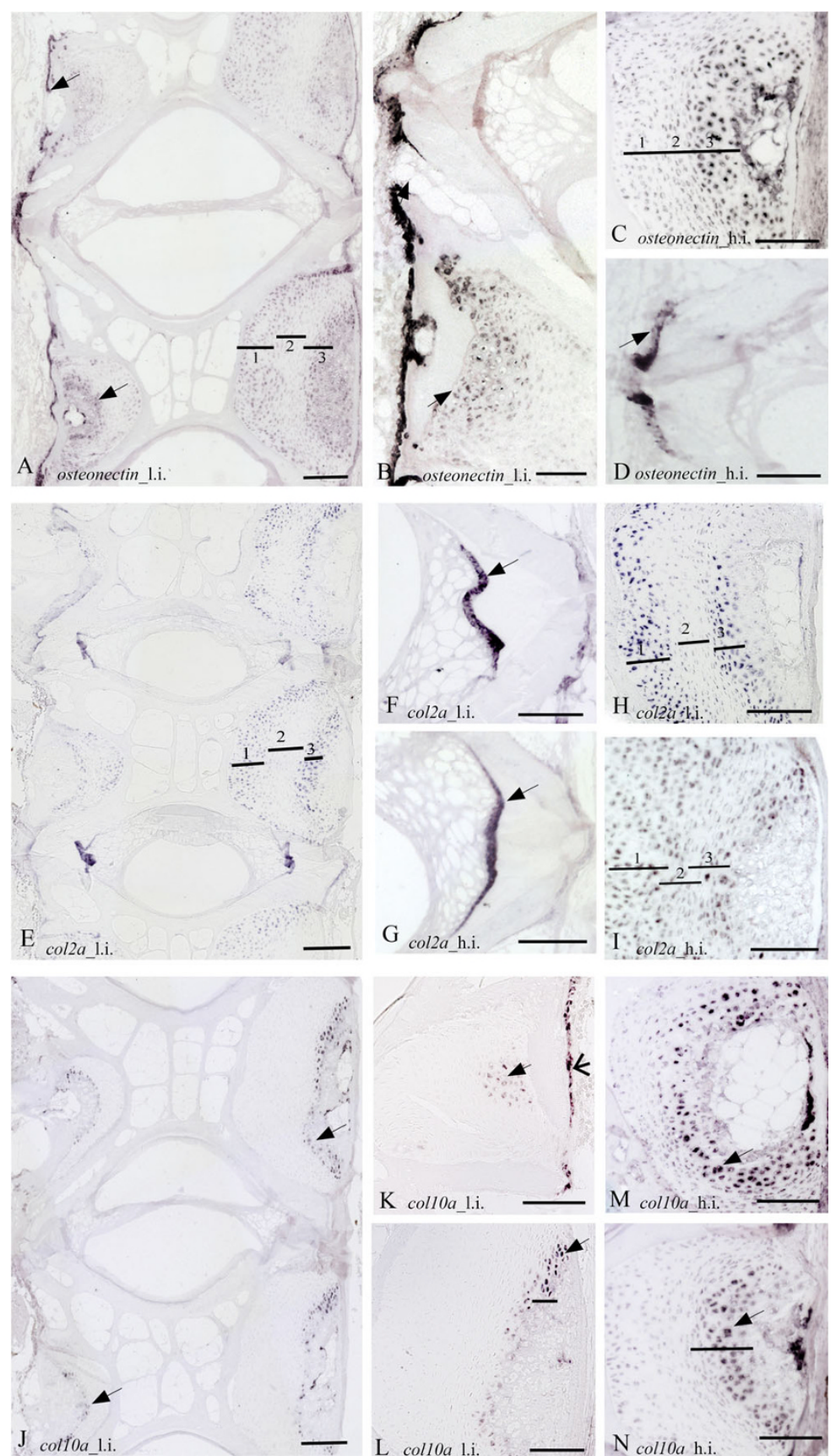

$$
\text { J colloa_li. }
$$
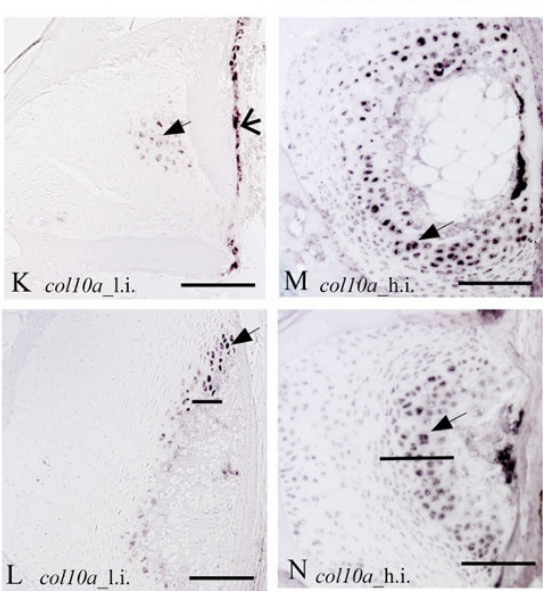

Figure 5 Transcription of osteonectin (A-D), col2a (E-I) and col10a (J-N) in parasagittal sections of phenotypical normal vertebrae from $15 \mathrm{~g}$ salmon reared at low intensive (l.i.) and high intensive (h.i.) temperature intensive regime. Numbered bars indicate zones of chondrocytes divided into the sub-groups: 1.resting, 2.proliferating and 3.hypertrophic chondrocytes. A. Osteonectin specific staining of two vertebrae from l.i. revealed staining in zone 1 and 2. B. Strong transcription of osteonectin is present in osteoblasts lining the growth zone at the endbone and in the hypertrophic chondrocytes (arrow) in l.i. C. The arch centra from h.i. Notice increased transcription of osteonectin; $\mathbf{D}$ Transcription of osteonectin in osteoblasts from h.i. appears decreased compared to l.i. E. Col2a staining of 3 vertebrae from I.i. Col2a mRNA localized to chondrocytes in zone 1 and 2. F. Higher magnification show distinct staining of col2a in the chordoblasts. G. Higher magnification of the arch centra with col2a mRNA in zone 1 and 2 . $\mathbf{H}$. In the corresponding area of h.i. a similar, but weaker pattern of col2a transcription is visible in the chordoblasts. I. Increased temperature lead to a distorted morphology and a more homogenous but weaker staining of col2a. $\mathbf{J}$ Staining of a large section from l.i. covering 2 vertebrae show that col10a mRNA localizes to zone 3 (arrows). $\mathbf{K}$. and $\mathbf{L}$. Higher magnification reveal col10a specific staining in hypertrophic chondrocytes (arrow) and along the rims of the vertebral body (arrowhead). Black bar indicates the narrow zone of transcription restricted to hypertrophic chondrocytes. $\mathbf{M}$ and $\mathbf{N}$. Corresponding area from h.i. show a wider zone of colloa

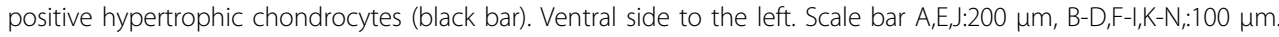




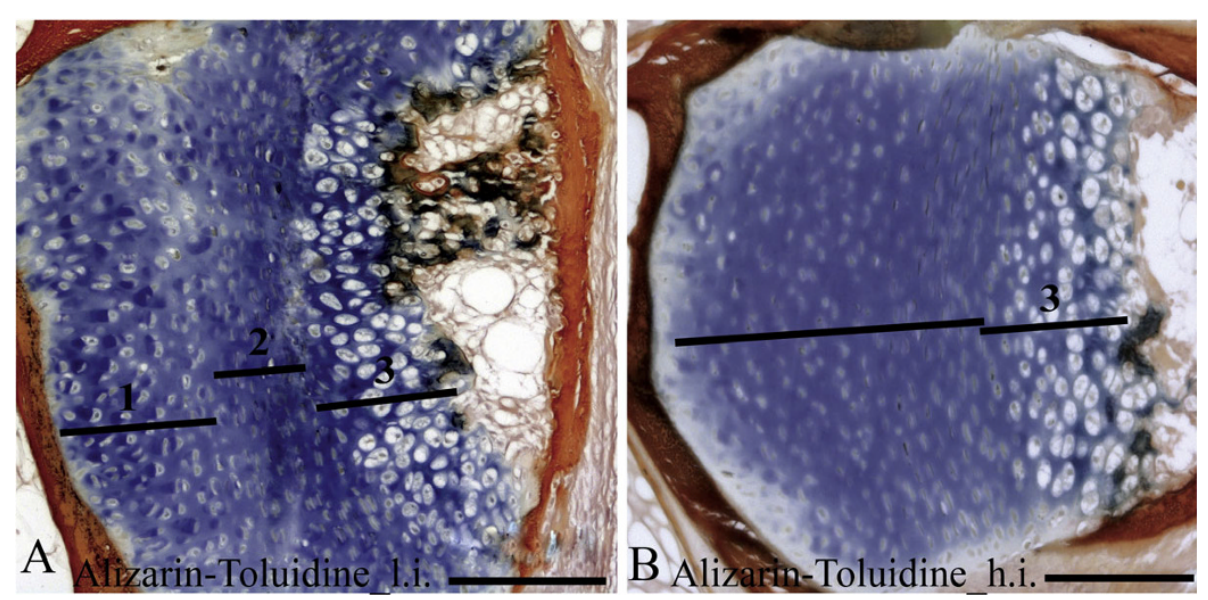

Figure 6 Parasagittal sections from $15 \mathrm{~g}$ salmon vertebrae stained with alizarin red-toluidine blue, showing the arch centra (dorsal side). A. The chondrocytes localize into bands of 1. resting, 2. proliferating and 3. hypertrophic chondrocytes in fish reared at low temperature. B. In comparison, a high temperature regime results in a more uniform cartilage structure without the distinct chondrocytes sub-populations and the hypertrophic chondrocytes appears less calcified. Scale bar: $100 \mu \mathrm{m}$.

bands of both low and high intensive group, but the mRNA expression was more evenly distributed in all cells of the latter group (Figure $5 \mathrm{H}, \mathrm{I}$ ). There were also generally less proliferating chondrocytes that tended to be less compact in this group. In proliferating chondrocytes we detected strong col $2 a$ mRNA expression in the high intensive group, but no expression in the low intensive group. Analysis of col10a showed restriction to the pre-hypertrophic and hypertrophic chondrocytes located in the deep cartilage zone (Figure 5M, N). Osteonectin was also expressed in chondrocytes and the signal increased towards the hypertrophic chondrocytes (Figure $5 \mathrm{~A}-\mathrm{C})$. The pre-hypertrophic chondrocyte zone was found to be expanded in the high intensive fish and both col10a1 and osteonectin showed an expanded expression domain corresponding to an increased hypertrophic zone. No signal was detected in any of the samples hybridized with sense probes (data not shown).

In normal spinal columns from the low intensive group, positive TRAP staining was detected at the ossifying boarders of the hypertrophic chondrocytes in the arch centra. No positive staining was detected in samples from the high intensive group (Figure 7A, B).

\section{Discussion}

The presented study aims at describing the molecular pathology underlying the development of vertebral deformities in Atlantic salmon reared at a high temperature regime that promotes fast growth during the early life stages. Within the period investigated, vertebral bodies form and develop and the skeletal tissue mineralizes. Rearing at high temperatures resulted in higher frequencies of vertebral deformities, as expected. The vertebral pathology observed in this study was most likely induced both during the embryonic development and after start-feeding, since the incidence of deformities continued to increase throughout the experiment after the first radiographic examination at $2 \mathrm{~g}$. Similar temperature regimes before and after start-feeding have independently been shown to induce vertebral defects in juvenile salmon $[1,26]$. However, whereas high temperatures during embryonic development is commonly related to somitic segmentation failure, deformities later in development may possibly be linked to fast growth induced by elevated temperatures and the impact this might have on the natural maturation and ontogeny of the vertebral bodies $[3,10,11]$. This causative relation has been shown for fast growing underyearling smolt that has a higher incidence of vertebral deformities than slower growing yearling smolt [27]. Further, morphometric analyses showed that elevated water temperature and faster growth is manifested by a difference in length-height proportion of vertebrae between fish from the two temperature regimes. Similar decrease in length-height proportion was described for the rapidgrowing underyearling smolt [27]. Radiographic observations indicated a lower level of mineralization of osteoid tissues in the high temperature fish. However, we could not find any pronounced altered mineral content between the two temperature regimes. The observed values were low compared to reference values [23], but in a range commonly observed in commercially reared salmon. Apparently, whole body mineral analysis seems insufficient to assess problems related to the development of spinal deformities.

To determine whether the difference in likelihood of developing vertebral deformities between the two groups could be traced back to an altered gene transcription, 


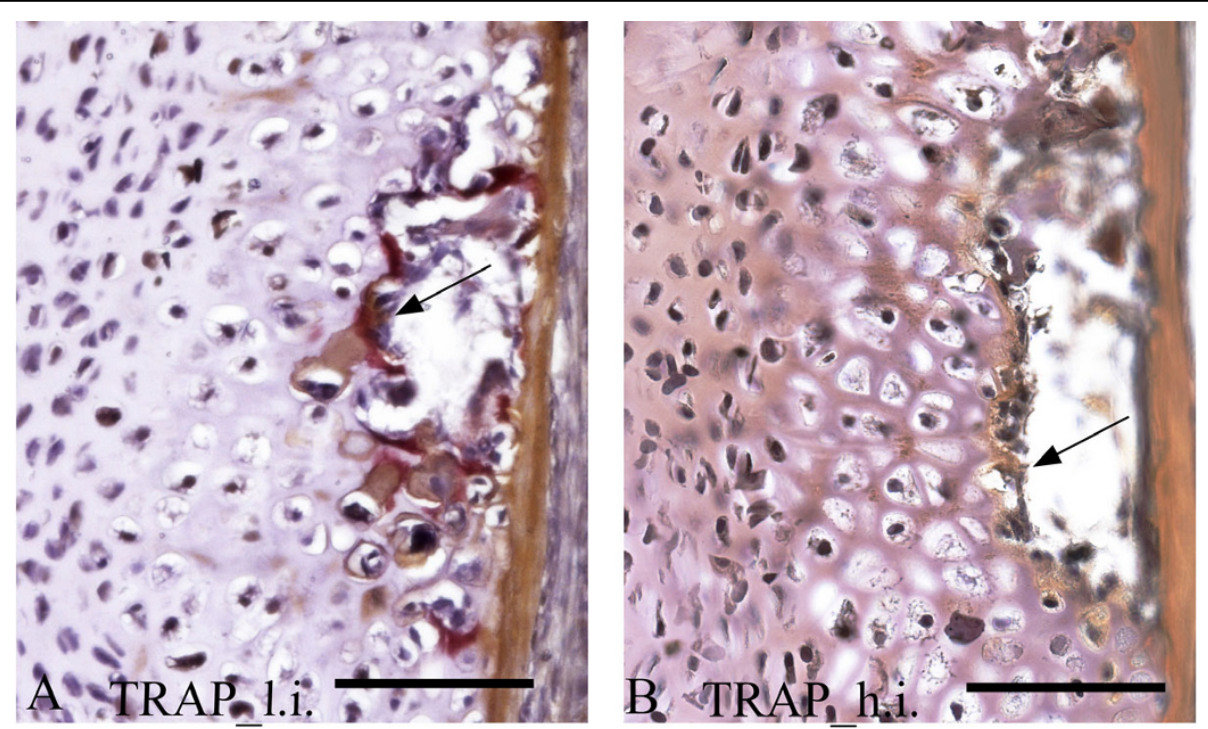

Figure 7 staining of parasagittal sections from $15 \mathrm{~g}$ salmon vertebrae, showing the arch centra (dorsal side). A. Positive staining (arrow) in the erosive front of cartilage indicating born resorption in neural arches of spinal columns from the low temperature group. B. No TRAP activity was found in the corresponding areas (indicated with an arrow) in samples from the high temperature group. Scale bar: $100 \mu \mathrm{m}$.

we examined the expression of selected skeletal mRNAs in phenotypical normal salmon fry at 2 and $15 \mathrm{~g}$. Histological examination of $15 \mathrm{~g}$ fish was included to improve interpretation of the transcriptional data. The selected genes showed conservation and similar spatial expression with those examined in other vertebrates, supporting that most of the factors and pathways that control skeletal formation are highly conserved in vertebrates.

The lower transcription of ECM genes such as colla1, osteocalcin, osteonectin and decorin suggests a defect in the late maturation of osteoblasts $[17,21,28]$. The correlation to impaired mineralization is supported by the shorter vertebral bodies in the high intensive groups throughout the study, as well as the impaired mineralization indicated by low contrast observed on X-ray. Col1a1 is the primary ECM component secreted by osteoblasts in the trabecular bone and growth plate and defects in the synthesis of coll or type 1 procollagen have been found in several heritable disorders of connective tissue. Likewise, defects in the assembly of Col1 fibrils have been reported to cause abnormally thin and branched structures [29]. Decreased diameter and crosslink density of the collagen fibers have been suggested to reduce thermal stability of collagen and thereby the tissues ability to support load during elevated temperatures [30]. In chum salmon, Oncorhynchus keta, the denaturation temperature of collagen type 1 from skin has been reported to be about $19^{\circ} \mathrm{C}$ [31]. The collagen fibres are further organized and stabilized by a range of non-collagenous proteins, which functions by linking other proteins and minerals to the ECM scaffold.
Decorin, which belongs to the small leucine rich repeat proteoglycan (PG) group (SLRPs) is involved in determining the mature collagen fibril structural phenotype and tissue function by facilitating protein-protein interaction with a range of other matrix components (mainly collagen fibres) and with the mineral phase during the formation of calcified tissues [32]. As a result, decorin has been shown to increase tensile strength of the collagen-decorin fiber [33]. Further, osteonectin is a phosphorylated glycoprotein that binds to collagen fibrils, calcium, and hydroxyapatite, linking the bone mineral and collagen phases and perhaps initiating active mineralization in normal skeletal tissue $[17,34]$. Osteonectinnull mice display decreased trabecular bone volume and have bone of lesser stiffness than control mice [35]. Osteocalcin mRNA expression also serves as a useful molecular marker of mineralization because it is associated with the maturation of bone cells and mineralization $[18,36]$. Alp is another marker gene for bone cell maturation and mineralization. Inhibition of alp activation, by for example heat or by gene knockout, inhibits calcification and causes mineralization defects in cultured bone cells and mice [37]. In addition, mutations in the alp gene lead to hypophosphatasia, in which bone matrix formation occurs, but mineralization is inhibited [38]. Our results showed that alp was down-regulated in the high intensive $15 \mathrm{~g}$ group, but up-regulated in $2 \mathrm{~g}$ fish. This may indicate that alp is a limiting factor for mineralization after long term exposure to the high temperature regime. Altogether, the simultaneous downregulation of genes encoding structural proteins taking 
part in the bone matrix and mineralization strongly supports an assumption that disturbances of these processes constitute an important part of the mechanisms of development of vertebral deformities.

As for the ECM genes involved in osteoblast development and mineralization, high intensive temperature treatment had a significant effect on the transcription of transcription factors and signaling molecules involved in these processes. Intriguingly, Runx 2 and Osterix, known as master regulators of osteoblast differentiation $[39,40]$, exhibited opposite mRNA expression levels at 2 and $15 \mathrm{~g}$. Runx2-null mice have osteoblast differentiation arrested [41], while osterixnull mice embryos have a significant reduction of col1 expression and do not express the late osteoblast specific marker osteocalcin [39]. In addition, we analyzed the bHLH transcription factor twist. This gene works as a negative regulator of osteoblastogenesis by inhibiting expression of genes downstream of runx2 [42]. At $2 \mathrm{~g}$ when osterix and twist was down-regulated while runx2 was up-regulated, osteocalcin was heavily downregulated as was colla1. The mRNA expression pattern was inverted at $15 \mathrm{~g}$. Then osterix and twist was upregulated and runx2 down-regulated, while osteocalcin and colla1 were weakly down-regulated. Linking these results to the pathways involved in osteoblast development, the required simultaneous activation of osterix and runx 2 did not appear at $2 \mathrm{~g}$ or at $15 \mathrm{~g}$. However, Osterix function downstream of Runx2 during osteoblast differentiation, but may be regulated by Bmp2 in a Runx2-independent pathway [43]. Bmp2 can induce ectopic bone and cartilage formation in adult vertebrates [44]. Spinella-Jaegle et al [16] found that cooperation between Bmp2 and Shh was necessary to promote a strong induction of the osteoblast marker alp in human mesenchymal cell lines. At both 2 and $15 \mathrm{~g}$, bmp 2 was highly up-regulated in the high intensive group, possibly as a response to the low ECM mRNA expression and under-mineralized tissue. In addition, osterix and shh was up-regulated at $15 \mathrm{~g}$, as was bmp4. Bmp4 treatment has been shown to stimulate new bone formation and is also expressed in osteoblasts prior to formation of mineralized bone nodules $[45,46]$. However, in comparison to Spinella-Jaegles in vitro findings, we did not detect an increase in alp mRNA expression. Further, we detected a weaker signal of osteocalcin and osteonectin in osteoblasts from the $I S H$ of the high intensive group at $15 \mathrm{~g}$. Hence, despite the possible attempt of $b m p 2$ to restore bone formation and mineralization, there was still lower transcription of ECM components in the high intensive group at $15 \mathrm{~g}$. Summarized, our results may indicate that osteoblast proliferation and mineralization were restrained in the fast growing group.
The percentage of deformities significantly increased in the high intensive group from $2 \mathrm{~g}$ till $15 \mathrm{~g}$, while the percentage was stable in the low intensive group. Hence, this period seems to involve important steps for the developmental fate of deformities. Between these two size stages we observed a change in expression pattern, from a downregulated to an upregulated transcription, of 9 genes, where 8 of them are involved in chondrogenesis. This suggested that chondrocytes go through changes in this period that could be important for the development of the observed pathologies.

In vertebrates as mouse and human $[47,48]$, the growth zones of long bones consists of well defined layers of progenitor, proliferative and hypertrophic chondrocytes [49]. These chondrocytes differ in their morphology, proliferation abilities and secretion of ECM components. For example, transcription of col $2 a 1$ is characteristic for the proliferative state whereas colloa 1 is restricted to the hypertrophic state $[47,50]$. ISH of these genes revealed that $15 \mathrm{~g}$ Atlantic salmon raised at the low intensive regime also had distinct sub-populations of progenitor, proliferative and hypertrophic chondrocytes at the growth zone of the neural and haemal arches. On the contrary, more distorted layers were found in Atlantic salmon raised at the high intensive regime. Moreover, an increased zone of hypertrophic chondrocytes was found in the proximity of the mineralized bone matrix in the high intensive group. Once these hypertrophic chondrocytes are fully differentiated, matrix calcification would normally be initiated [12]. However, we could not identify any variance in mineralization at the ossifying borders of the hypertrophic chondrocytes when examined by histological Alizarin red $\mathrm{S}$ staining.

The increased zone of hypertrophic chondrocytes in the high intensive group and the up-regulated transcription of hypertrophic marker genes suggest an arrest prior to the final maturation of chondrocytes. Thus, these chondrocytes seems unable to initiate mineralization. The chondrocyte hypertrophy marker col10a1 and its activator mef2c [51] were both up-regulated at $15 \mathrm{~g}$ in the high intensive group. Moreover, $i h h$, a repressor of terminal hypertrophic differentiation [52], was found to be highly up-regulated, whereas $\operatorname{sox} 9$, which is involved in early chondrocyte differentiation, and its downstream structural protein $\operatorname{col} 2 a$ [53], were downregulated. The severely down-regulation of runx2 at $15 \mathrm{~g}$ is of interest, since runx2-null mice embryos have a narrow zone of proliferating chondrocytes and a wide zone of hypertrophic chondrocytes [54]. In addition, bmp4, which was up-regulated at $15 \mathrm{~g}$, has been shown to accelerate the hypertrophic maturation process [55]. Interestingly, we also found an up-regulated expression of $p d g f r b$ mRNA at $15 \mathrm{~g}$. Kieswetter and collaborators 
[25] have reported that chondrocytes respond to PDGF by enhancing proliferation and cartilage matrix production while maintaining the cells in a less mature phenotype; corroborating our findings that the chondrocytes are some how arrested in the late hypertrophic stage at $15 \mathrm{~g}$ with a reduced possibility of completing the endochondral ossification process with calcified bone as end product. Similar findings have also been shown in rat ulnae, where loading was associated with an increased hypertrophic zone in the growth plate [56], but mineralization rate was suppressed [57]. Another interesting comparative pathological condition to our findings in salmon is tibial dyschondroplasia (TD), a metabolic disease of young poultry that affects the growth of bone and cartilage. The lesion is morphologically characterized by an accumulation of chondrocytes that appear to be unable to differentiate past a pre-hypertrophic stage [58]. TD often occurs in broilers and other poultry that have been bred for fast growth rates. The tibial cartilage does not mature enough to ossify, which leaves the growth plate prone to fracture, infection, and deformed bone development.

The observed shorter phenotype of vertebral bodies from the high intensive group might have been a consequence of higher mechanical load in fast growing fish coincidental with a lower transcription of supportive ECM components. Together with the up-regulation of hypertrophic genes in high intensive fish at $15 \mathrm{~g}$, we also found increased transcription of vimentin. Vimentin filaments have been shown to regulate the swelling pressure of chondrocytes [59] and strengthen resistance to mechanical stress [60]. Hence, the increased activation of vimentin and the increased proportion of hypertrophic chondrocytes in the high intensive temperature group at $15 \mathrm{~g}$ may reflect an adaptation to the fast growth by prioritizing maturation of chondrocytes that are more resistant to mechanical stress. At $2 \mathrm{~g}$, however, the reduced level of vimentin mRNAs might possibly be linked to the mal-adaptive down-regulation of chondrocytic genes in high intensive group. Indeed, disruption of vimentin filaments has been shown to result in loss of cell contact with the surrounding matrix which may alter the signaling dynamics of the cell and in effect shut down transcriptional events [24].

Mineralizing hypertrophic chondrocytes acquire and express most of the phenotypic characteristics of osteoblasts, including high Alp activity and expression of osteonectin and osteocalcin [61]. These phenotypic traits shared with osteoblasts may be needed to bring about the final phase of endochondral ossification and replace mineralized cartilage with bone [62]. They may also permit mineralized cartilage to act as bone-like structural tissue and allow for a transition from cartilage to bone. In contrast to the down-regulated transcription of osteonectin and osteocalcin, as determined by real time qPCR, we observed an increased transcription pattern of these genes in the arch centra in the high intensive group by $I S H$. We also observed a tendency of lower transcription of the same genes in osteoblasts of the high intensive group. However, establishment of a calcifiable matrix requires degradation of some matrix molecules. Endochondral bone formation includes the participation of MMPs, which degrade cartilage matrix and allow vascular invasion [63]. At least two proteases are involved in this process; MMP13 which regulates remodeling of the hypertrophic cartilage matrix and MMP9 which has a role in vascularisation of the growth plate $[64,65]$. When analyzing these MMPs in salmon vertebral columns, a significant down-regulation of both $m m p 9$ and $m m p 13$ in the high intensive group at $2 \mathrm{~g}$ were observed. At $15 \mathrm{~g}, m m p 13 \mathrm{mRNA}$ expression decreased even more, while $m m p 9$ was significantly upregulated. Indeed, MMP13 is known as the dominant collagenase in cartilage and its absence cause delay in endochondral ossification [65]. Further supporting the hypothesis that endochondral ossification was in some way delayed in the spinal columns from the high intensive group, runx 2 deficiency has been shown to inhibit mmp expression [66] and lead to mild disturbances of chondrocyte differentiation, as discussed above. In addition, TRAP activity, essential for completing endochondral ossification [22], was absent in the erosive front of cartilage in neural and heamal arches of spinal columns from the high temperature group.

\section{Conclusion}

The presented results contribute to the understanding of the mechanisms involved in development of temperature-induced vertebral pathology by describing changes in vertebral tissue not yet manifesting pathological deviations. Our results strongly indicate that temperature induced fast growth is severely affecting gene transcription in osteoblasts and chondrocytes, leading to a change in the tissue structure and composition. The data presented here indicate that both production of bone and cartilage were disrupted when promoting fast growth using elevated temperature. It is not unlikely that this disequilibrium is involved in the higher rate of deformities observed in the high intensive group. Importantly, management control of deformities and health in general demands precise tools and knowledge to depict any problem as early as possible in the production line. The defined markers of bone and cartilage cell differentiation and matrix formation can be used to investigate how the progression of skeletogenesis is modulated by a variety of factors. Even though differences in the two experimental groups were undetectable externally, rearing at increased temperatures induced consistent 
transcriptional changes in several genes that correlated with the higher risk of developing deformities later in ontogeny. Hence, this article reveals the potential use of gene transcription profiling as a prognostic approach in aquaculture.

\section{Methods}

\section{Experimental design}

The fish experiment was done at Nofima Marine at Sunndalsøra, Norway, in 2007 with Atlantic salmon from the Salmobreed strain. Two experimental temperature regimes were set up; a high intensive temperature group and a low intensive temperature group (Figure 8). Pooled batches of unfertilized eggs and milt were transported on ice to the hatchery and were fertilized, rinsed and disinfected according to standard procedures. The eggs were incubated in a hatchery designed for incubation of small egg volumes, with approximately 0.2 liters of eggs per unit in six units per temperature regime. During egg rearing water supply was continuous from two temperature controlled tanks stabilized at $10 \pm 0.3^{\circ}$ $\mathrm{C}$ and $6 \pm 0.3^{\circ} \mathrm{C}$, respectively, monitored twice daily. At $850 \mathrm{~d}^{\circ}$ (day degrees = sum of daily temperature), a selection of fry were mixed and transferred to 150 liter tanks for start-feeding, four tanks per temperature regime. The number of fry per tank was 400 . Water flow in the tanks was adjusted throughout the experimental period to secure oxygen supply in excess. The fish were fed commercial diets and the light was continuous. The temperature for the high intensive tanks was gradually increased at first feeding to $16 \pm 0.3^{\circ} \mathrm{C}$ and the temperature for the low intensive tanks was gradually increased to $10 \pm 0.3^{\circ} \mathrm{C}\left(1^{\circ} \mathrm{C}\right.$ per day). These temperatures were kept stable until the average size in each group reached $20 \mathrm{~g}$. At this size, the differentiated temperature treatment was ended. 100 fish per tank were selected randomly, and were tagged individually with pit-tags in the abdominal cavity. Fish from the four tanks on same temperature regime were mixed in a larger tank, and reared at ambient temperature until termination at $60 \mathrm{~g}$. Specific growth rates (SGR) in the period between startfeeding and $60 \mathrm{~g}$ were measured according to equation $\left.\mathrm{SGR}=\left((\text { endweight } / \text { startweight })^{\wedge(1 / \text { days })}-1\right) \times 100\right)$.

\section{Tissue sampling, radiography, morphology and mineral analyses}

Vertebral columns of phenotypically normal specimens from both temperature groups were sampled for gene expression analysis at 2 and $15 \mathrm{~g}$ size and histological analysis at $15 \mathrm{~g}$ size. The term phenotypically normal was defined as vertebral columns without any obvious aberrations or deformities when imaged by radiography at sampling. For this purpose, fish were heavily sedated in MS 222 (Tricaine methane sulphate, Pharmaq, Overhalla, Norway) (150 mg/litre) and imaged with an IMS Giotto mammography system (model number 6020/3, IMS Giotto, Bologna, Italy) equipped with a FCR Profect phosphorus film plate (Fuji Medical Inc., Japan). The resulting 20 pixels/mm images were enhanced with digital software (Fuji Computed Radiography Console) and evaluated manually concurrent with sampling. Fish without any specific pathology of the vertebral column were identified for sampling, and killed by an anesthetic overdose. Approximately $\sim 5$ vertebral bodies $(\sim 1 \mathrm{~cm})$ were carefully dissected from the area under the dorsal fin. For gene expression analyses, samples were flash-frozen

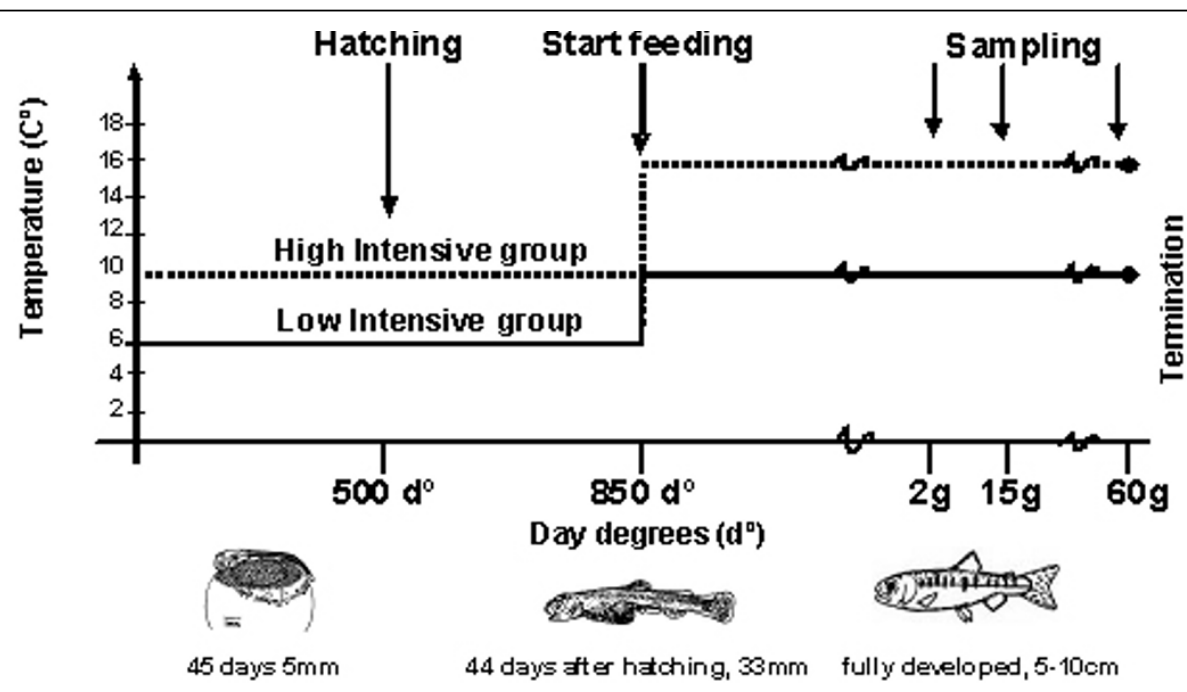

Figure 8 Experimental overview of the two temperature regimes. Developmental stage is shown along the $x$-axis and temperature along the $y$-axis. The low temperature intensive rearing conditions are shown as a black line and the high temperature intensive conditions as a stippled line. Sampling was conducted at $2 \mathrm{~g}, 15 \mathrm{~g}$ and $60 \mathrm{~g}$. Experiment was terminated when the fish reached $60 \mathrm{~g}$. 
in liquid nitrogen and transported on dry-ice to a $-80^{\circ} \mathrm{C}$ freezer for storage. For histological analysis, vertebrae were fixated in $4 \%$ PFA for $24 \mathrm{~h}$ at $4^{\circ} \mathrm{C}$, dehydrated in ethanol (25, 50 and 70\%) and stored at 70\% ethanol at $-20^{\circ} \mathrm{C}$. At $2 \mathrm{~g}$ size, 350 fish were screened and a total of 40 were sampled for this study. At $15 \mathrm{~g}$ size, 900 fish were screened, and 70 were sampled. Fish that were not selected for sampling following radiography were transferred to clean water and returned to the rearing tank. At $60 \mathrm{~g}$ size, following an on-growing period on ambient temperatures, 800 fish were radiographed, 100 per original first feeding tank.

Incidence of skeletal deformities was recorded on radiographs from all samplings, and the presence or absence of vertebral pathology was recorded. It should be noted that fish with deviant vertebral morphology, mainly those with fusion type changes, were heavily sampled on basis of live X-ray at $2 \mathrm{~g}$ and $15 \mathrm{~g}$ (Ytteborg, manuscript in progress). This gives an underestimation of the differences between the two groups. In order to quantify differences observed in proportions of vertebral bodies, length and height of vertebral bodies were measured on X-rays (ImageJ 1.39, NIH, USA), The length (craniocaudal) and height (dorsoventral) of 5 vertebral bodies under the dorsal fin was measured in 12 individuals from each group at 2, $15 \mathrm{~g}$ and $60 \mathrm{~g}$, and the length: height ratio was calculated.

At termination of the experiment, fish were sampled for analysis of whole body mineral content. Four samples per treatment were taken, one per each of the original first feeding tanks. Each sample consisted of 10 fish, which were pooled before analysis. The samples were stored frozen at $-20^{\circ} \mathrm{C}$, and were homogenized prior to analysis. The dry matter of samples was determined after drying at $104^{\circ} \mathrm{C}$ for $16 \mathrm{~h}$. For mineral analysis, samples were prepared as described $[67,68]$ before analyzed by inductive coupled plasma (ICP) massspectroscopy.

\section{Statistical analyses}

A one-way analysis of variance model on incidence of deformities were carried out by SAS 9.1 software (SAS Institute Inc., USA), including the fixed effect of temperature regime. Statistics for gene transcription analysis are described in the real time qPCR section.

\section{RNA isolation and CDNA synthesis}

Tissue homogenization from 15 replicates from each treatment and developmental stage was achieved in a mortar with liquid nitrogen. Total RNA from the powdered vertebrae was isolated by using $\mathrm{TRIzol}^{\mathrm{TM}}$ and Micro to Midi Kit ${ }^{\oplus}$ (Invitrogen, MD, USA). Samples were treated with DNase1 (Invitrogen) before cDNA synthesis using oligo(dT) and Taqman Gold RT-PCR kit
(Applied Biosystems, CA, USA). The cDNA synthesis was performed with 10 min primer incubation at $25^{\circ} \mathrm{C}$, $60 \mathrm{~min} \mathrm{RT}$ step at $48^{\circ} \mathrm{C}$ and $5 \mathrm{~min} \mathrm{RT}$ inactivation at $95^{\circ} \mathrm{C}$ in accordance to the manufacturer's protocol. All reactions were performed in accordance to the manufacturer's protocol.

\section{Sequence information and primer design}

Primers for expression analysis were based on known Atlantic salmon sequences or on conserved regions of known teleost sequences paralogues. Primers were designed using the Vector NTI Advance 10 (Life technologies, MD, USA), and NetPrimer (PREMIER Biosoft, CA, USA) software. All PCR products were cloned using pGEM T-easy (Promega, WI, USA) and sequenced with Big Dye Terminator chemistry and the ABI 3730 automated sequencer, both delivered by Applied Biosystems. The obtained Atlantic salmon sequences were analyzed by BLAST and deposited in the Genbank database (Table 2).

\section{Real time PCR}

Triplicate real-time $\mathrm{qPCR}$ reactions were performed using the Light cycler 480 and SYBR Green chemistry (Roche, Switzerland) at the following thermal cycling conditions: $95^{\circ} \mathrm{C}$ for $10 \mathrm{~min}$, followed by 45 cycles at $95^{\circ} \mathrm{C}$ for $15 \mathrm{~s}, 60 \pm 1^{\circ} \mathrm{C}$ for $15 \mathrm{~s}$ and $72^{\circ} \mathrm{C}$ for $15 \mathrm{~s}$. Further, specificity was assessed by the melting curves, determined post PCR $\left(95^{\circ} \mathrm{C}\right.$ for $15 \mathrm{~s}, 60^{\circ} \mathrm{C}$ for $1 \mathrm{~min}$ and $97^{\circ} \mathrm{C}$ continuous). PCR efficiencies for each target and the three housekeeping genes; elongation factor 1 a (ella), heat shock protein $90 \beta$ (hsp90\%) and glyceraldehyde 3-phosphate dehydrogenase (gapdh) were tested as endogenous controls. Relative target gene mRNA was normalized to relative ella mRNA levels for all sample, as recommended by Olsvik et al. [69]. The transcription ratios of the 20 genes in all individual vertebrae from the two developmental stages were tested by using the Relative Expression Software Tool, REST, according to Pfaffl et al. [70]. Differences between the transcription ratios were tested for significance by the Pair Wise Fixed Reallocation Randomization Test ${ }^{\odot}$ [70].

\section{In situ hybridization and histology}

Samples of phenotypically normal vertebrae from low and high intensive group at the $15 \mathrm{~g}$ developmental stage were analyzed by $I S H$ and histological analysis. Samples were dehydrated stepwise for $24 \mathrm{~h}$ and clearing carried out in xylene (Merck, Darmstadt, Germany) for $2 \times 24$ h before embedding in Technovit 9100 (Heraeus Kulzer, GmbH, Wehrheim, Germany), according to the procedure described by Torgersen et al. [71]. Parasagittal serial sections were cut from vertebral columns by using a Microm HM 355S (Thermo Fisher scientific 
Table 2 Primers used for Real time qPCR (RT) and probes for in situ hybridization (ISH)

\begin{tabular}{|c|c|c|c|c|c|}
\hline Gene & Orientation & Genbank & $\mathrm{Tm}$ & Use & Sequence $\left(5^{\prime}-3^{\prime}\right)$ \\
\hline \multicolumn{6}{|c|}{ Extracellular Matrix constituents } \\
\hline \multirow[t]{4}{*}{ Col1a1 } & Forward & FJ195608 & 68.6 & RT & AGAGAGGAGTCATGGGACCCGT \\
\hline & Reverse & & 68.8 & $\mathrm{RT}$ & GGGTCCTGGAAGTCCCTGGAAT \\
\hline & Forward & & 69.8 & ISH & TAGCCGTGGTTTCCCTGGTT \\
\hline & Reverse & & 68.7 & ISH & CCGGGAGGTCCAAATCTACC \\
\hline \multirow[t]{4}{*}{ Col2a1 } & Forward & FJ195613 & 62.6 & RT & TGGTCGTTCTGGAGAGACT \\
\hline & Reverse & & 62.7 & $\mathrm{RT}$ & CCTCATGTACCTCAAGGGAT \\
\hline & Forward & & 64.4 & ISH & GCTGGCGAGACAGGAGAGA \\
\hline & Reverse & & 63.4 & $\mathrm{ISH}$ & GCCTCATCAGCCCTCATGTA \\
\hline \multirow[t]{4}{*}{ Col10a1 } & Forward & EG837148 & 66.4 & RT & TGGTGCTCTITGACTGCCTGTAA \\
\hline & Reverse & & 65.1 & $\mathrm{RT}$ & CATCCTGTGTGTTGCAATATCACA \\
\hline & Forward & & 61.9 & $\mathrm{ISH}$ & AACAAGGGCTTCTTGGATCA \\
\hline & Reverse & & 60.9 & ISH & CATAATGCATCCTCAGGCAT \\
\hline \multirow[t]{2}{*}{ ALP } & Forward & FJ195609 & 62.6 & RT & CTAGTTTGGGTCGTGGTATGT \\
\hline & Reverse & & 62.2 & RT & TGAGGGCATTCTTCAAAGTA \\
\hline \multirow[t]{4}{*}{ Osteocalcin } & Forward & FJ195611 & 62.9 & RT & GTGAACCAACAGCAAAGAGA \\
\hline & Reverse & & 62.8 & RT & CCAGGTCCTTCTTAACAAACA \\
\hline & Forward & & 59.6 & ISH & CTCATACTTGTTGATCGTCCAG \\
\hline & Reverse & & 60.2 & ISH & TCTITCTCTCTCGCTCTCCC \\
\hline \multirow[t]{4}{*}{ Osteonectin } & Forward & FJ195614 & 65.3 & RT & ATTACTGAGGAGGAGCCCATCATT \\
\hline & Reverse & & 65.9 & RT & СCTCATCCACCTCACACACCTT \\
\hline & Forward & & 64.6 & $\mathrm{ISH}$ & CTGAACGATGAGGGTGTGGA \\
\hline & Reverse & & 67.2 & ISH & CGAGTGGTGCAGTGCTCCAT \\
\hline \multirow[t]{2}{*}{ Decorin } & Forward & DQ452069 & 65.0 & RT & GAACCTGGCTAAGCTGGGTCTAA \\
\hline & Reverse & & 66.0 & RT & GAACAGGCTGATGCCAGAGTACAT \\
\hline \multirow[t]{2}{*}{ MMP9 } & Forward & CA342769 & 65.9 & RT & AGTCTACGGTAGCAGCAATGAAGGC \\
\hline & Reverse & & 65.7 & RT & CGTCAAAGGTCTGGTAGGAGCGTAT \\
\hline \multirow[t]{2}{*}{ MMP13 } & Forward & DW539943 & 66.9 & RT & TGATGTCCAAGTCAGCCGCTTC \\
\hline & Reverse & & 63.6 & RT & AAGGAGGCAGGAGGAAGAGG \\
\hline \multirow[t]{2}{*}{ Vimentin } & Forward & GE618371 & 62.5 & RT & CAAGATCCTGTTAGCAGAGCT \\
\hline & Reverse & & 67.8 & RT & TGGTCTGCCACTTGCGATTGTC \\
\hline \multicolumn{6}{|c|}{ Transcription factors } \\
\hline \multirow[t]{2}{*}{ Sox9 } & Forward & EU344852 & 62.8 & RT & CCTGCAAACAAGACAAGGT \\
\hline & Reverse & & 62.8 & RT & GGGTCGAGTAGATTCATACGA \\
\hline \multirow[t]{2}{*}{ Runx2 } & Forward & FJ195615 & 64.8 & RT & CCACCAGGGACAGACACAGAT \\
\hline & Reverse & & 64.0 & RT & GAACGGACTGAGATCTGACGAA \\
\hline \multirow[t]{2}{*}{ Osterix } & Forward & FJ195612 & 63.0 & RT & TCCCATAGACTTTCCCACA \\
\hline & Reverse & & 62.9 & RT & TGCCTCAGGACATGTACAA \\
\hline \multirow[t]{2}{*}{ Mef2c } & Forward & GU252207 & 62.5 & RT & CACCGTAACTCGCCTGGTCT \\
\hline & Reverse & & 62.3 & RT & GCTTGCGGTTGCTGTTCATA \\
\hline \multirow[t]{2}{*}{ Twist* } & Forward & AY546100 & 61.8 & RT & GCTTCAAAAGTGGAGACCGTT \\
\hline & Reverse & & 61.6 & RT & GGGAGAACTTGAGCCCTCTTC \\
\hline \multicolumn{6}{|c|}{ Signalling molecules: } \\
\hline \multirow[t]{2}{*}{ BMP4 } & Forward & FJ195610 & 62.2 & RT & TCAAGTTGCCCATAGTCAGT \\
\hline & Reverse & & 62.6 & RT & CACCTGAACTCTACCAACCA \\
\hline \multirow[t]{2}{*}{ BMP2 } & Forward & ВT059611 & 62.5 & RT & ATGTGGTATTGCACCCATT \\
\hline & Reverse & & 62.9 & RT & ATGGACAGTTTCCCAATGA \\
\hline Shh* & Forward & AY370830 & 61.7 & RT & CCGGCTCATGACTCAGAGATG \\
\hline & Reverse & & 62.2 & RT & TATCCCTGGCCACTGGTTCA \\
\hline Ihh & Forward & FJ195617 & 63.2 & RT & GGCTCAATCTCCTCTCTCCAAT \\
\hline & Reverse & & 63.3 & RT & GCTTGGTTGGGAGATATGCA \\
\hline
\end{tabular}


Table 2: Primers used for Real time qPCR (RT) and probes for in situ hybridization (ISH) (Continued)

\begin{tabular}{|c|c|c|c|c|c|}
\hline \multirow[t]{2}{*}{ PDGFrb } & Forward & BT071824 & 62.2 & RT & TAGGACCAGCCGATGTTACTGC \\
\hline & Reverse & & 62.9 & RT & TCTCTGAGCCTCTCGATGT \\
\hline \multicolumn{6}{|c|}{ Housekeeping genes: } \\
\hline \multirow[t]{2}{*}{$\overline{E F 1 a^{* *}}$} & Forward & DQ834870 & 71.3 & RT & CACCACCGGCCATCTGATCTACAA \\
\hline & Reverse & & 69.4 & RT & TCAGCAGCCTCCTTCTCGAACTTC \\
\hline \multirow[t]{2}{*}{$\mathrm{GAPDH}^{* * *}$} & Forward & BT043825.1 & 72.4 & RT & TGGTGCAGAACCTCATGGTCCTCA \\
\hline & Reverse & & 70.2 & RT & ATCCCGGATGATTCCAAAGTCGTC \\
\hline \multirow[t]{2}{*}{ Hsp9o $\beta^{* * *}$} & Forward & BX074486 & 59.7 & RT & AATGGGTAACCTGGTCAGTG \\
\hline & Reverse & & 60.6 & RT & GACTCAGGCAAAGGAACCTT \\
\hline
\end{tabular}

*Wargelius et al. [3] **Olsvik et al. [69] ***Takle et al. [2]

Inc., PA, USA) and mounted on pre-coated slides $(0.01 \%$ Poly-L-lysine (Sigma) and 2\% polyvinyl acetate glue (Casco, Arnheim, Germany)). ISH was carried out with digoxigenine labeled (DIG RNA Labeling Kit, Roche) probes as described [71]. A total of five ECM producing genes were analyzed, including col1a, col2a, col10a, osteocalcin and osteonectin.

Histological examination of vertebrae with toluidine blue and alizarin red S double staining was carried out on deplastified and rehydrated sections. Briefly, the sections were stained for $2-3 \mathrm{~min}$ at RT in $0.1 \%$ toluidine blue (Sigma-Aldrich) ( $\mathrm{pH} \mathrm{2.3)}$ and rinsed in distilled $\mathrm{H}_{2} \mathrm{O}$ followed by alizarin red (Sigma-Aldrich) (pH 4.2) staining for $5 \mathrm{~min}$. Prior to microscopy, the stained sections were dehydrated in ethanol and mounted with Cytoseal 60 (Electron Microscopy Science, Fort Washington, PA, USA). Bright field microscopic analyses were performed on a Zeiss Axio Observer equipped with an AxioCam MRc5 camera and AxioVision software (Carl Zeiss Microimaging GmbH, Göttingen, Germany).

Specimens for paraffin embedding were stepwise rehydrated in ethanol (50 and 25\%) and decalcified for 7 days in 10\% EDTA solution buffered with $0.1 \mathrm{M}$ Tris base (Merck) at $\mathrm{pH}$ 7.0. The decalcified specimens were rinsed in PBS and stepwise dehydrated in ethanol (50, 70 and $100 \%$ ), before being embedded in paraffin. We used 3 paraffin infiltration steps carried out at $60^{\circ} \mathrm{C}$ for $2 \times 2 \mathrm{~h}$ and $1 \times 3 \mathrm{~h}$. The specimens were embedded in paraffin, stiffened at room temperature and hardened over night at $4^{\circ} \mathrm{C} .5 \mu \mathrm{m}$ serial sections were prepared using a Microm HM 355S. Paraffin sections were floated on demineralised water $\left(25^{\circ} \mathrm{C}\right)$, mounted on uncoated slides and dried $\mathrm{ON}$ at $37^{\circ} \mathrm{C}$. Prior to staining the sections were de-waxed with Clear Rite (Richard-Allan, MI, USA), followed by $2 \times$ washes in xylene (Merck) for 5 min each. Sections were then rehydrated before rinsed in $\mathrm{dH}_{2} \mathrm{O}$. To demonstrate TRAP activity, the Acid phosphatase leukocyte kit No. 387 (Sigma-Aldrich) was used and followed according to the manufacturer's protocol; except that incubation lasted for $2 \mathrm{~h}$ at $37^{\circ} \mathrm{C}$.
Subsequently, slides were rinsed in $\mathrm{dH}_{2} \mathrm{O}$. Specimens were counterstained with Mayers hematoxylin (SigmaAldrich) for $30 \mathrm{~s}$ and rinsed in running tap water before dehydrated, cleared and mounted with Cytoseal 60 (Electron Microscopy Science). Controls were incubated without substrate.

\section{Abbreviations}

ALP: alkaline phosphatase; BCIP/NBT: 5-bromo-4-chloro-3 indolyl phosphate p-toluidine salt/nitro blue tetrazolium chloride; bHLH: basic helix loop helix; BMP: bone morphogenetic proteins; dl: deciliter, Gla: y-carboxyglutamic acid; Ihh: indian hedge hog; MMP: matrix metalloproteinase; PBS: phosphatebuffered saline; PDGFrb: platelet derived growth factor receptor b; PFA: paraformaldehyde; Runx2: runt related transcription factor 2; shh: Sonic hedge hog; Sox9: sex determining region Y-box 9; TRAP: Tartrate-resistant acid phosphatase.

\section{Acknowledgements}

The authors are grateful to Asbjørn Valset, Britt Seljebø and Kjellrun Gannestad for technical assistance during the project. The study was supported by The Norwegian Research Council (project no 172483) and EU (COLL-CT-2005-012451, FINE FISH).

\section{Author details}

${ }^{1}$ Nofima Marin, Norwegian Institute of Food, Fisheries and Aquaculture Research, P.O. Box 5010, NO-1432 Ås, Norway. ${ }^{2}$ Norwegian University of Life Sciences, NO-1432 Ås, Norway. ${ }^{3}$ AVS Chile SA, Imperial 0655, Of. 3A, Puerto Varas, Chile.

\section{Authors' contributions}

EY carried out the molecular studies, participated in sampling and drafted the manuscript. GB carried out the radiological diagnostics, accompanied in statistical analysis and participated in the experimental design. $\mathrm{KH}$ radiographed the fish and participated in the diagnostics and statistical analysis. JT participated in the design of the ISH experiments, sequence alignment and probe design, microscopic analyzes and acquisition and interpretation of data. HT conceived the study and its experimental and molecular design, coordinated the sampling, and participated in acquisition and interpretation of data and in the drafting of the manuscript. All authors read and approved the final manuscript.

Received: 29 June 2009 Accepted: 6 July 2010 Published: 6 July 2010

References

1. Ornsrud R, Gil L, Waagbo R: Teratogenicity of elevated egg incubation temperature and egg vitamin A status in Atlantic salmon, Salmo salar L. Journal of Fish Diseases 2004, 27:213-223.

2. Takle $H$, Baeverfjord $G$, Lunde M, Kolstad $K$, Andersen $O$ : The effect of heat and cold exposure on HSP70 expression and development of deformities during embryogenesis of Atlantic salmon (Salmo salar). Aquaculture 2005, 249:515-524. 
3. Wargelius A, Fjelldal PG, Hansen T: Heat shock during early somitogenesis induces caudal vertebral column defects in Atlantic salmon (Salmo salar). Dev Genes Evol 2005, 215:350-357.

4. Ornsrud R, Gil L, Waagbo R: Teratogenicity of elevated egg incubation temperature and egg vitamin A status in Atlantic salmon, Salmo salar L. Journal of Fish Diseases 2004, 27:213-223.

5. Georgakopoulou E, Angelopoulou A, Kaspiris P, Divanach P, Koumoundouros G: Temperature effects on cranial deformities in European sea bass, Dicentrarchus labrax (L.). Journal of Applied Ichthyology 2007, 23:99-103.

6. Casadevall M, Casinos A, Viladiu C, Ontanon M: Scaling of Skeletal Mass and Mineral-Content in Teleosts. Zoologischer Anzeiger 1990, 225:144-150

7. Nordvik K, Kryvi H, Totland GK, Grotmol S: The salmon vertebral body develops through mineralization of two preformed tissues that are encompassed by two layers of bone. J Anat 2005, 206:103-114.

8. Boivin G, Meunier PJ: Changes in bone remodeling rate influence the degree of mineralization of bone. Connective Tissue Research 2002, 43:535-537.

9. Hernandez CJ, Beaupre GS, Carter DR: A model of mechanobiologic and metabolic influences on bone adaptation. Journal of Rehabilitation Research and Development 2000, 37:235-244.

10. Fjelldal G, Hansen TJ, Berg AE: A radiological study on the development of vertebral deformities in cultured Atlantic salmon (Salmo salar L.). Aquaculture 2007, 273:721-728.

11. Fjelldal PG, Nordgarden U, Berg A, Grotmol S, Totland GK, Wargelius A, Hansen T: Vertebrae of the trunk and tail display different growth rates in response to photoperiod in Atlantic salmon, Salmo salar L., postsmolts. Aquaculture 2005, 250:516-524.

12. Breur GJ, Vanenkevort BA, Farnum CE, Wilsman NJ: Linear Relationship Between the Volume of Hypertrophic Chondrocytes and the Rate of Longitudinal Bone-Growth in Growth Plates. Journal of Orthopaedic Research 1991, 9:348-359.

13. Karsenty G: Transcriptional control of skeletogenesis. Annual Review of Genomics and Human Genetics 2008, 9:183-196.

14. Karp SJ, Schipani E, St-Jacques B, Hunzelman J, Kronenberg H, McMahon AP: Indian hedgehog coordinates endochondral bone growth and morphogenesis via Parathyroid Hormone related-Protein-dependent and -independent pathways. Development 2000, 127:543-548.

15. Hogan BLM: Bone morphogenetic proteins in development. Current Opinion in Genetics \& Development 1996, 6:432-438.

16. Spinella-Jaegle $S$, Rawadi G, Kawai $S$, Gallea S, Faucheu C, Mollat $P$, Courtois B, Bergaud B, Ramez V, Blanchet A, Baron R, Roman-Roman S: Sonic hedgehog increases the commitment of pluripotent mesenchymal cells into the osteoblastic lineage and abolishes adipocytic differentiation. Journal of Cell Science 2001, 114:2085-2094.

17. Termine JD, Kleinman HK, Whitson SW, Conn KM, Mcgarvey ML, Martin GR: Osteonectin, A Bone-Specific Protein Linking Mineral to Collagen. Cell 1981, 26:99-105

18. Cowles EA, Derome ME, Pastizzo G, Brailey LL, Gronowicz GA: Mineralization and the expression of matrix proteins during in vivo bone development. Calcified Tissue International 1998, 62:74-82

19. Glimcher MJ: Recent Studies of the Mineral Phase in Bone and Its Possible Linkage to the Organic Matrix by Protein-Bound Phosphate Bonds. Philosophical Transactions of the Royal Society of London Series B-Biological Sciences 1984, 304:479.

20. Glimcher MJ: Mechanism of Calcification - Role of Collagen Fibrils and Collagen Phosphoprotein Complexes Invitro and Invivo. Anatomical Record 1989, 224:139-153

21. Boskey AL: Mineral-Matrix Interactions in Bone and Cartilage. Clinical Orthopaedics and Related Research 1992, 244-274.

22. Witten $P E$, Huysseune $A: A$ comparative view on mechanisms and functions of skeletal remodelling in teleost fish, with special emphasis on osteoclasts and their function. Biological Reviews 2009, 84:315-346.

23. Shearer KD, Asgard T, Andorsdottir G, Aas GH: Whole-Body Elemental and Proximate Composition of Atlantic Salmon (Salmo-Salar) During the LifeCycle. Journal of Fish Biology 1994, 44:785-797.

24. Blain EJ, Gilbert SJ, Hayes AJ, Duance VC: Disassembly of the vimentin cytoskeleton disrupts articular cartilage chondrocyte homeostasis. Matrix Biology 2006, 25:398-408
25. Kieswetter K, Schwartz Z, Alderete M, Dean DD, Boyan BD: Platelet derived growth factor stimulates chondrocyte proliferation but prevents endochondral maturation. Endocrine 1997, 6:257-264.

26. Siemien MJ, Carline RF: Effect of Temperature on the Growth of 1StFeeding Atlantic Salmon Fry. Progressive Fish-Culturist 1991, 53:11-14.

27. Fjelldal PG, Lock EJ, Grotmol S, Totland GK, Nordgarden U, Flik G, Hansen T: Impact of smolt production strategy on vertebral growth and mineralisation during smoltification and the early seawater phase in Atlantic salmon (Salmo salar, L.). Aquaculture 2006, 261:715-728.

28. Mochida Y, Duarte WR, Tanzawa H, Paschalis EP, Yamauchi M: Decorin modulates matrix mineralization in vitro. Biochemical and Biophysical Research Communications 2003, 305:6-9.

29. Ishida Y, Kubota H, Yamamoto A, Kitamura A, Bachinger HP, Nagata K: Type I collagen in Hsp47-null cells is aggregated in endoplasmic reticulum and deficient in $\mathrm{N}$-propeptide processing and fibrillogenesis. Molecular Biology of the Cell 2006, 17:2346-2355.

30. Naimark WA, Waldman SD, Anderson RJ, Suzuki B, Pereira CA, Lee JM: Thermomechanical analysis of collagen crosslinking in the developing lamb pericardium. Biorheology 1998, 35:1-16.

31. Kimura S, Zhu XP, Matsui R, Shijoh M, Takamizawa S: Characterization of Fish Muscle Type-I Collagen. Journal of Food Science 1988, 53:1315-1318.

32. Weber IT, Harrison RW, lozzo RV: Model structure of decorin and implications for collagen fibrillogenesis. Journal of Biological Chemistry 1996, 271:31767-31770

33. Pins GD, Christiansen DL, Patel R, Silver FH: Self-assembly of collagen fibers. Influence of fibrillar alignment and decorin on mechanical properties. Biophysical Journal 1997, 73:2164-2172.

34. Bolander ME, Young MF, Fisher LW, Yamada Y, Termine JD: Osteonectin Cdna Sequence Reveals Potential Binding Regions for Calcium and Hydroxyapatite and Shows Homologies with Both A BasementMembrane Protein (Sparc) and A Serine Proteinase-Inhibitor (Ovomucoid). Proceedings of the National Academy of Sciences of the United States of America 1988, 85:2919-2923.

35. Delany AM, Amling M, Priemel M, Howe C, Baron R, Canalis E: Osteopenia and decreased bone formation in osteonectin-deficient mice. Journal of Clinical Investigation 2000, 105:915-923.

36. Furie $B$, Furie $B C$ : Molecular-Basis of Gamma-Carboxylation - Role of the Propeptide in the Vitamin K-Dependent Proteins. Annals of the New York Academy of Sciences 1991, 614:1-10.

37. Klein BY, Gal I, Segal D: Studies of the Levamisole Inhibitory Effect on Rat Stromal-Cell Commitment to Mineralization. Journal of Cellular Biochemistry 1993, 53:114-121.

38. Wennberg C, Hessle L, Lundberg P, Mauro S, Narisawa S, Lerner UH, Millan JL: Functional characterization of osteoblasts and osteoclasts from alkaline phosphatase knockout mice. Journal of Bone and Mineral Research 2000, 15:1879-1888.

39. Nakashima K, Zhou X, Kunkel G, Zhang ZP, Deng JM, Behringer RR, de Crombrugghe $B$ : The novel zinc finger-containing transcription factor Osterix is required for osteoblast differentiation and bone formation. Cell 2002, 108:17-29.

40. Ducy P, Zhang R, Geoffroy V, Ridall AL, Karsenty G: Osf2/Cbfa1: A transcriptional activator of osteoblast differentiation. Cell 1997, 89:747-754.

41. Komori T, Yagi H, Nomura S, Yamaguchi A, Sasaki K, Deguchi K, Shimizu Y, Bronson RT, Gao YH, Inada M, Sato M, Okamoto R, Kitamura Y, Yoshiki S, Kishimoto T: Targeted disruption of Cbfa1 results in a complete lack of bone formation owing to maturational arrest of osteoblasts. Cell 1997, 89:755-764

42. Bialek P, Kern B, Yang XL, Schrock M, Sosic D, Hong N, Wu H, Yu K, Ornitz DM, Olson EN, Justice MJ, Karsenty G: A twist code determines the onset of osteoblast differentiation. Developmental Cell 2004, 6:423-435.

43. Liu TJ, Gao YH, Sakamoto K, Minamizato T, Furukawa K, Tsukazaki T, Shibata Y, Bessho K, Komori T, Yamaguchi A: BMP-2 promotes differentiation of osteoblasts and chondroblasts in Runx2-deficient cell lines. Journal of Cellular Physiology 2007, 211:728-735.

44. Musgrave DS, Bosch P, Ghivizzani S, Robbins PD, Evans CH, Huard J: Adenovirus-mediated direct gene therapy with bone morphogenetic protein-2 produces bone. Bone 1999, 24:541-547. 
45. Chen D, Harris MA, Rossini G, Dunstan CR, Dallas SL, Feng JQ, Mundy GR, Harris SE: Bone morphogenetic protein 2 (BMP-2) enhances BMP-3, BMP4 , and bone cell differentiation marker gene expression during the induction of mineralized bone matrix formation in cultures of fetal rat calvarial osteoblasts. Calcified Tissue International 1997, 60:283-290.

46. Harris SE, Sabatini M, Harris MA, Feng JQ, Wozney J, Mundy GR: Expression of Bone Morphogenetic Protein Messenger-Rna in Prolonged Cultures of Fetal-Rat Calvarial Cells. Journal of Bone and Mineral Research 1994, 9:389-394.

47. Castagnola P, Dozin B, Moro G, Cancedda R: Changes in the Expression of Collagen Genes Show 2 Stages in Chondrocyte Differentiation Invitro. Journal of Cell Biology 1988, 106:461-467.

48. Long FX, Zhang XYM, Karp S, Yang YZ, McMahon AP: Genetic manipulation of hedgehog signaling in the endochondral skeleton reveals a direct role in the regulation of chondrocyte proliferation. Development 2001, 128:5099-5108.

49. Hunziker EB, Schenk RK: Physiological-Mechanisms Adopted by Chondrocytes in Regulating Longitudinal Bone-Growth in Rats. Journal of Physiology-London 1989, 414:55-71.

50. Kielty CM, Kwan APL, Holmes DF, Schor SL, Grant ME: Type-X Collagen, A Product of Hypertrophic Chondrocytes. Biochemical Journal 1985, 227:545-554.

51. Arnold MA, Kim Y, Czubryt MP, Phan D, McAnally J, Qi X, Shelton JM, Richardson JA, Bassel-Duby R, Olson EN: MEF2C transcription factor controls chondrocyte hypertrophy and bone development. Developmental Cell 2007, 12:377-389.

52. Colnot C, de la Fuente L, Huang S, Hu D, Lu CY, St-Jacques B, Helms JA: Indian hedgehog synchronizes skeletal angiogenesis and perichondrial maturation with cartilage development. Development 2005, 132:1057-1067.

53. Bell DM, Leung KKH, Wheatley SC, Ng LJ, Zhou S, Ling KW, Sham MH, Koopman P, Tam PPL, Cheah KSE: SOX9 directly regulates the type-II collagen gene. Nature Genetics 1997, 16:174-178.

54. Inada M, Yasui T, Nomura S, Miyake S, Deguchi K, Himeno M, Sato M, Yamagiwa H, Kimura T, Yasui N, Ochi T, Endo N, Kitamura Y, Kishimoto T, Komori T: Maturational disturbance of chondrocytes in Cbfa1-deficient mice. Developmental Dynamics 1999, 214:279-290.

55. Shum L, Wang XB, Kane AA, Nuckolls GH: BMP4 promotes chondrocyte proliferation and hypertrophy in the endochondral cranial base. International Journal of Developmental Biology 2003, 47:423-431.

56. Robling AG, Duijvelaar KM, Geevers JV, Ohashi N, Turner CH: Modulation of appositional and longitudinal bone growth in the rat ulna by applied static and dynamic force. Bone 2001, 29:105-113.

57. Ohashi N, Robling AG, Burr DB, Turner $\mathrm{CH}$ : The effects of dynamic axial loading on the rat growth plate. Journal of Bone and Mineral Research 2002, 17:284-292.

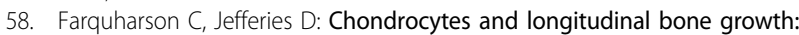
The development of tibial dyschondroplasia. Poultry Science 2000, 79:994-1004.

59. Durrant LA, Archer CW, Benjamin M, Ralphs JR: Organisation of the chondrocyte cytoskeleton and its response to changing mechanical conditions in organ culture. Journal of Anatomy 1999, 194:343-353.

60. Trickey WR, Vail TP, Guilak F: The role of the cytoskeleton in the viscoelastic properties of human articular chondrocytes. Journal of Orthopaedic Research 2004, 22:131-139.

61. Lian JB, Mckee MD, Todd AM, Gerstenfeld LC: Induction of Bone-Related Proteins, Osteocalcin and Osteopontin, and Their Matrix UltrastructuralLocalization with Development of Chondrocyte Hypertrophy Invitro. Journal of Cellular Biochemistry 1993, 52:206-219.

62. Kirsch T, Nah HD, Shapiro IM, Pacifici M: Regulated production of mineralization-competent matrix vesicles in hypertrophic chondrocytes. Journal of Cell Biology 1997, 137:1149-1160.

63. Vu TH, Shipley JM, Bergers G, Berger JE, Helms JA, Hanahan D, Shapiro SD, Senior RM, Werb Z: MMP-9/gelatinase $B$ is a key regulator of growth plate angiogenesis and apoptosis of hypertrophic chondrocytes. Cell 1998, 93:411-422.

64. Engsig MT, Chen QJ, Vu TH, Pedersen AC, Therkidsen B, Lund LR, Henriksen K, Lenhard T, Foged NT, Werb Z, Delaisse JM: Matrix metalloproteinase 9 and vascular endothelial growth factor are essential for osteoclast recruitment into developing long bones. Journal of Cell Biology 2000, 151:879-889.
65. Stickens D, Behonick DJ, Ortega N, Heyer B, Hartenstein B, Yu Y, Fosang AJ, Schorpp-Kistner M, Angel P, Werb Z: Altered endochondral bone development in matrix metalloproteinase 13-deficient mice. Development 2004, 131:5883-5895.

66. Pratap J, Javed A, Languino LR, van Wijnen AJ, Stein JL, Stein GS, Lian J.B: The Runx2 osteogenic transcription factor regulates matrix metalloproteinase 9 in bone metastatic cancer cells and controls cell invasion. Mol Cell Biol 2005, 25:8581-8591.

67. Denstadli V, Skrede A, Krogdahl A, Sahstrom S, Storebakken T: Feed intake, growth, feed conversion, digestibility, enzyme activities and intestinal structure in Atlantic salmon (Salmo salar L.) fed graded levels of phytic acid. Aquaculture 2006, 256:365-376.

68. Helland S, Denstadli V, Witten PE, Hjelde K, Storebakken T, Skrede A, Asgard T, Baeverfjord G: Hyper dense vertebrae and mineral content in Atlantic salmon (Salmo salar L.) fed diets with graded levels of phytic acid. Aquaculture 2006, 261:603-614.

69. Olsvik PA, Lie KK, Jordal AEO, Nilsen TO, Hordvik I: Evaluation of potential reference genes in real-time RT-PCR studies of Atlantic salmon. BmC Molecular Biology 2005, 6.

70. Pfaffl MW, Horgan GW, Dempfle L: Relative expression software tool (REST (c)) for group-wise comparison and statistical analysis of relative expression results in real-time PCR. Nucleic Acids Research 2002, 30.

71. Torgersen JS, Takle $H$, Andersen $O$ : Localization of mRNAs and Proteins in Methyl Methacrylate (MMA) Embedded Tissues. Journal of Histochem Cytochem 2009, 825-830.

doi:10.1186/1472-6793-10-12

Cite this article as: Ytteborg et al:: Molecular pathology of vertebral deformities in hyperthermic Atlantic salmon (Salmo salar). BMC Physiology 2010 10:12.

\section{Submit your next manuscript to BioMed Central and take full advantage of:}

- Convenient online submission

- Thorough peer review

- No space constraints or color figure charges

- Immediate publication on acceptance

- Inclusion in PubMed, CAS, Scopus and Google Scholar

- Research which is freely available for redistribution

Submit your manuscript at www.biomedcentral.com/submit
C Biomed Central 